University of Nebraska - Lincoln

DigitalCommons@University of Nebraska - Lincoln

${ }^{15} \mathrm{~N} /{ }^{14} \mathrm{~N}$ Variations in Cretaceous Atlantic Sedimentary Sequences: Implication for Past Changes in Marine Nitrogen Biogeochemistry

\author{
Greg H. Rau \\ Institute of Marine Sciences, University of California, Santa Cruz, CA 95064, and NASA-Ames Research \\ Center, Moffett Field, CA 94035 (U.S.A.) \\ Michael A. Arthur \\ University of Rhode Island \\ Walter E. Dean \\ USGS
}

Follow this and additional works at: https://digitalcommons.unl.edu/usgsstaffpub

Part of the Earth Sciences Commons

Rau, Greg H.; Arthur, Michael A.; and Dean, Walter E., " ${ }^{15} \mathrm{~N} /{ }^{14} \mathrm{~N}$ Variations in Cretaceous Atlantic Sedimentary Sequences: Implication for Past Changes in Marine Nitrogen Biogeochemistry" (1987). USGS Staff-- Published Research. 302.

https://digitalcommons.unl.edu/usgsstaffpub/302

This Article is brought to you for free and open access by the US Geological Survey at DigitalCommons@University of Nebraska - Lincoln. It has been accepted for inclusion in USGS Staff -- Published Research by an authorized administrator of DigitalCommons@University of Nebraska - Lincoln. 


\title{
${ }^{15} \mathrm{~N} /{ }^{14} \mathrm{~N}$ variations in Cretaceous Atlantic sedimentary sequences: implication for past changes in marine nitrogen biogeochemistry
}

\author{
Greg H. Rau ${ }^{1}$, Michael A. Arthur ${ }^{2}$ and Walter E. Dean ${ }^{3}$ \\ ' Institute of Marine Sciences, University of California, Santa Cruz, CA 95064, and NASA-Ames Research Center, \\ Moffett Field, CA 94035 (U.S.A.) \\ ${ }^{2}$ Graduate School of Oceanography, University of Rhode Island, Narragansett, RI 02882 (U.S.A.) \\ ${ }^{3}$ U.S. Geological Survey, Denver, CO 80225 (U.S.A.)
}

Received February 26, 1986; revised version received December 30, 1986

\begin{abstract}
At two locations in the Atlantic Ocean (DSDP Sites 367 and 530) early to middle Cretaceous organic-carbon-rich beds ("black shales") were found to have significantly lower $\delta^{15} \mathrm{~N}$ values (lower ${ }^{15} \mathrm{~N} /{ }^{14} \mathrm{~N}$ ratios) than adjacent organic-carbon-poor beds (white limestones or green claystones). While these lithologies are of marine origin, the black strata in particular have $\delta^{15} \mathrm{~N}$ values that are significantly lower than those previously found in the marine sediment record and most contemporary marine nitrogen pools. In contrast, black, organic-carbon-rich beds at a third site (DSDP Site 603) contain predominantly terrestrial organic matter and have $\mathrm{C}$ - and $\mathrm{N}$-isotopic compositions similar to organic matter of modern terrestrial origin.

The recurring ${ }^{15} \mathrm{~N}$ depletion in the marine-derived Cretaceous sequences prove that the nitrogen they contain is the end result of an episodic and atypical biogeochemistry. Existing isotopic and other data indicate that the low ${ }^{15} \mathrm{~N}$ relative abundance is the consequence of pelagic rather than post-depositional processes. Reduced ocean circulation, increased denitrification, and, hence, reduced euphotic zone nitrate availability may have led to Cretaceous phytoplankton assemblages that were periodically dominated by $\mathrm{N}_{2}$-fixing blue-green algae, a possible source of this sediment ${ }^{15} \mathrm{~N}$-depletion. Lack of parallel isotopic shifts in Cretaceous terrestrially-derived nitrogen (Site 603) argues that the above change in nitrogen cycling during this period did not extend beyond the marine environment.
\end{abstract}

\section{Introduction}

The existence of beds rich in organic carbon (OC) within Cretaceous marine sedimentary sequences has received considerable attention with regard to the paleoceanographic circumstances under which these reoccuring strata were formed (e.g. [1-2]). Such beds can contain up to $50 \%$ dry weight $\mathrm{OC}$, in contrast to interbedded lithologies that contain less than $0.5 \%$ OC. These and other geochemical differences between $\mathrm{OC}$-rich and OC-poor strata have been used to infer periodic, widespread enhanced preservation of terrestrial and (or) marine organic matter under reoccurring anaerobic sedimentary environments.

A recent study [3] of the stable isotope abundance of Cretaceous organic carbon concluded that Cretaceous marine photosynthesis fractionated carbon isotopes more than in most of the recent ocean. In an attempt to find independent evidence for differences between modern and
Cretaceous marine biogeochemical processes, we turned to measurement of ${ }^{15} \mathrm{~N} /{ }^{14} \mathrm{~N}$ ratios. The purpose of this paper is to document differences we have found in $\mathrm{N}$ isotope abundance between (1) Cretaceous OC-rich and OC-poor strata, and (2) Cretaceous OC-rich sediments and sediments of other ages; and to discuss how these differences may be related to historic changes in marine $\mathrm{N}$ cycling.

\section{Methods}

\subsection{Site and sample selection}

For this study we chose samples of interbedded OC-rich and OC-poor carbonate strata of Neocomian age from Deep Sea Drilling Project (DSDP) Sites 367 and 603 in the eastern and western basins of the North Atlantic Ocean respectively, and OC-rich and OC-poor claystones of Albian to Coniacian age from DSDP Site 530 in the Angola Basin South Atlantic Ocean (Fig. 1). 


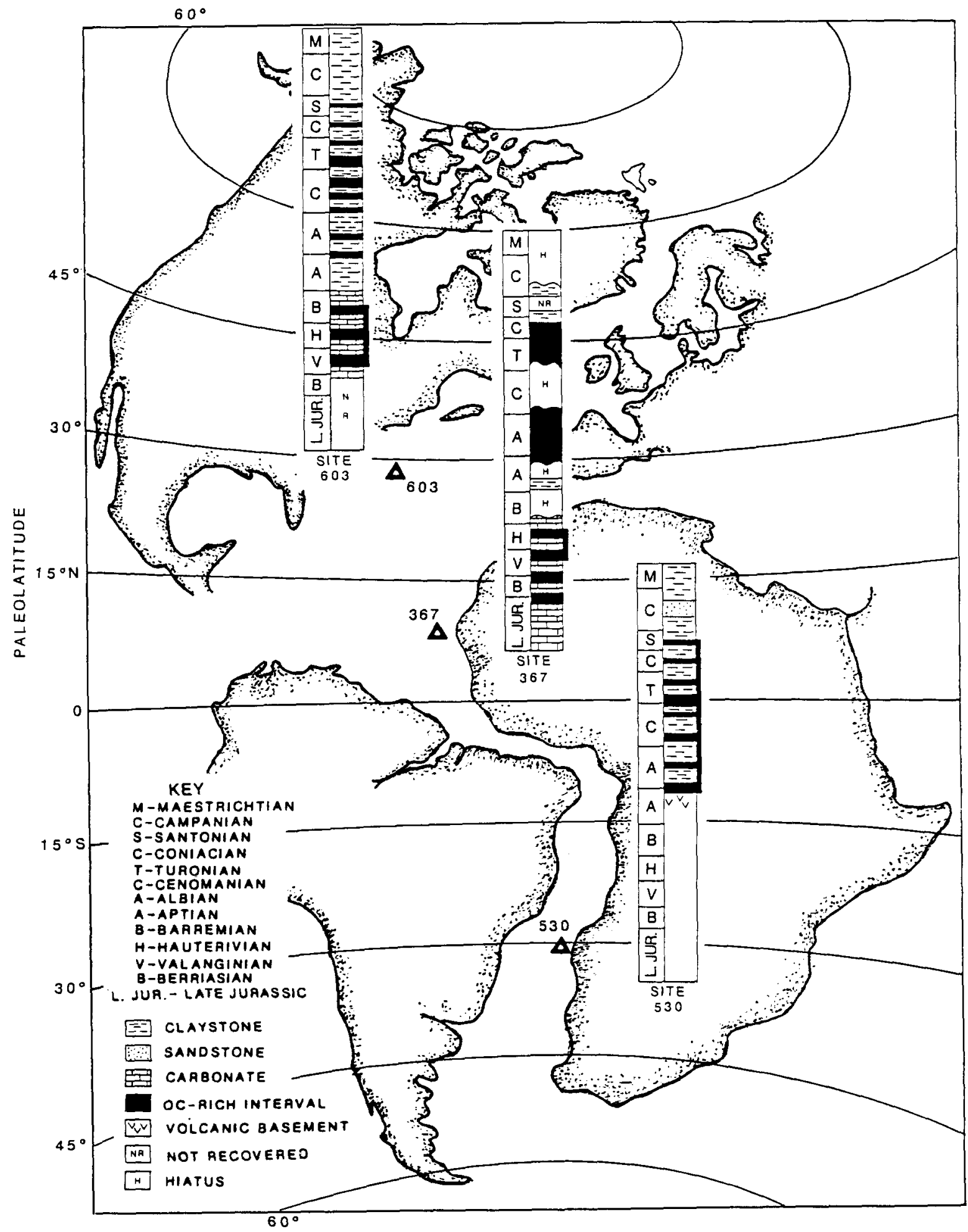

Fig. 1. Map of the Atlantic and adjacent continents at $100 \mathrm{Ma}$ (after Sclater et al. [48]) showing locations at DSDP Sites 367,503 , and 603. Generalized stratigraphic columns for each of the sites also are shown. Age ranges for samples used in this study are shown in brackets to the right of each stratigraphic column. The letters signify Cretaceous stages. 
Carbon isotopic and other geochemical measurements suggest that the organic matter in the Neocomian carbonates from Sites 367 and 603 represent predominantly marine and terrestrial end members, respectively, of organic matter entering the Early Cretaceous North Atlantic Ocean [3]. During the Cretaceous these two sites were located in very different geographic, oceanographic, and climatic settings; strong upwelling probably typified the region off the predominantly arid northwest African coast at Site 367 and more humid conditions with terrestrial runoff from poorly drained, coal-forming coastal wetlands of eastern North America are recorded at Site 603 [4]. The black claystones at Site 530 in the southern Angola Basin recorded the variable influx of organic matter into a predominantly red-clay depositional environment [5]. The accumulation of organic matter at Site 530 reached a maximum near the Cenomanian-Turonian boundary, a period of known increased world-wide accumulation and burial of marine organic matter [6]. The Cenomanian/Turonian section at Site 530 should, therefore, contain a record of predominantly marine production in a marginal upwelling regime within a partly restricted proto-South Atlantic Ocean (Fig. 1).

\subsection{Nitrogen isotope analyses}

A total of 1-5 grams of dried, powdered sediment sample were acidified with an excess of $5 \mathrm{~N}$ $\mathrm{HCl}$ and the resulting solution dried at $60^{\circ} \mathrm{C}$. Subsamples weighing 50-150 mg of each acidified sample were then loosely encased in precombusted silver foil and placed in a precombusted quartz tube $(7 \mathrm{~mm}$ i.d., $30 \mathrm{~cm}$ long, one end sealed). Approximately one gram each of precombusted $\mathrm{CuO}$ and $\mathrm{Cu}$ particles (30 mesh) also was placed in the tube and the contents placed under vacuum for about four hours. The tubes were then sealed using a gas-oxygen torch, and heated to $800^{\circ} \mathrm{C}$ for six hours in a muffle furnace. The $\mathrm{N}_{2}$ gas produced was then cryogenically purified and manometrically measured. The stable-nitrogen isotope abundance in each gas sample was analyzed using a Nuclide 6-60 isotope-ratio mass spectrometer. By convention, the ${ }^{15} \mathrm{~N} /{ }^{14} \mathrm{~N}$ ratio of each sample is reported as the relative per mil difference between the sample ratio and the ratio of $\mathrm{N}_{2}$ in air.
That is:

$\delta^{15} \mathrm{~N}(\%)=[R($ sample $) / R($ air $)-1] \times 1000$

where $R={ }^{15} \mathrm{~N} /{ }^{14} \mathrm{~N}$. The analytical precision (SD) of these measurements is $\pm 0.2 \%$. Each $\mathrm{N}_{2}$ gas sample was scanned for the presence of NO (mass 30) and $\mathrm{O}_{2}$ (mass 32). These masses were never found in concentrations significantly above background, indicating that the sediment nitrogen had been quantitatively converted to $\mathrm{N}_{2}$ and that there was negligible contamination from atmospheric sources during sample/gas handling.

\section{Results and discussion}

The most striking and obvious results of the $\delta^{15} \mathrm{~N}$ analyses are that many of the Cretaceous samples have $\delta^{15} \mathrm{~N}$ values that are lower than those of most forms of particulate nitrogen in the modern aquatic-sedimentary $\mathrm{N}$-cycle, and that the most OC-rich sediments have the lowest $\delta^{15} \mathrm{~N}$ values (Table 1, Fig. 2). The majority of our Cretaceous samples clearly have lower $\delta^{15} \mathrm{~N}$ and $\delta^{13} \mathrm{C}$ values than plankton from Peru coastal upwelling areas, North Pacific particulate organic matter (POM), Holocene shelf sediments from the U.S. Atlantic margin, and Holocene to Miocene sediments from the Southern California borderland (Fig. 3). Many of our Cretaceous $\delta^{15} \mathrm{~N}$ values are also below those encountered in Permian coals [7] and Precambrian kerogens [8]. There are few examples of negative $\delta^{15} \mathrm{~N}$ values in modern marine particulate or sediment nitrogen, whereas most of our OC-rich Cretaceous samples have negative $\delta^{15} \mathrm{~N}$ values.

The $\delta^{15} \mathrm{~N}$ of total nitrogen (TN) and other geochemical parameters for the DSDP Atlantic Cretaceous samples (Table 1) indicates that the source and(or) diagenetic history of nitrogen is significantly different between adjacent relatively OC-rich and OC-poor layers. The depletion in ${ }^{15} \mathrm{~N}$ of most of our Cretaceous samples, and of OC-rich layers in particular, shows that the conditions under which the source of the sediment $\mathrm{N}$ formed (source effects) or the conditions of post-depositional, diagenetic alteration were different than in most modern to ancient marine sediments. Which of these effects, $\mathrm{N}$ source or $\mathrm{N}$ diagenesis, are then reflected in the sediment $\mathrm{N}$ isotope abundances we have observed? 
TABLE 1

Lithology, sample identification, and $\delta^{15} \mathrm{~N}$ (this report); and ancillary data from Dean et al. [3] and unpublished

\begin{tabular}{|c|c|c|c|c|c|c|c|c|}
\hline Sample description & Site & Core-sec-int & $\begin{array}{l}\% \mathrm{C}_{\text {org }} \\
(\mathrm{RE})\end{array}$ & $\begin{array}{l}\text { Atom. } \\
\mathrm{C} / \mathrm{N}\end{array}$ & Index ${ }^{a}$ & $\begin{array}{l}\delta^{13} \mathrm{C} \\
(\%)\end{array}$ & $\begin{array}{l}\delta^{15} \mathrm{~N} \\
(\%)\end{array}$ & $\begin{array}{l}\not \mathrm{CaCO}_{3} \\
\text { (XRF) }\end{array}$ \\
\hline Laminated black marlstone & 367 & $25-4-117$ & 2.38 & 30 & 265 & -27.9 & 0.12 & \\
\hline Laminated black marlstone & 367 & $26-1-88$ & 2.82 & 21 & 376 & -27.7 & -1.67 & \\
\hline Laminated black marlstone & 367 & $26-2-63$ & 2.24 & 27 & 263 & -28.0 & 0.58 & \\
\hline Laminated black marlstone & 367 & $26-3-70$ & 2.79 & 25 & 312 & -28.1 & -1.07 & \\
\hline Laminated black marlstone & 367 & $26-3-110$ & 1.78 & 24 & 344 & -28.3 & 0.21 & \\
\hline Bioturbated white limestone & 367 & $25-3-64$ & 0.07 & 30 & 200 & -27.0 & 5.02 & \\
\hline Bioturbated white limestone & 367 & $25-3-130$ & 0.07 & 27 & 171 & -27.3 & 2.33 & \\
\hline Bioturbated white limestone & 367 & $26-2-50$ & 0.04 & - & 225 & -27.4 & 3.15 & \\
\hline Bioturbated white limestone & 367 & $26-2-50$ & 0.04 & - & 225 & -27.4 & 2.77 & \\
\hline Bioturbated white limestone & 367 & $26-2-70$ & 0.08 & 21 & 112 & -27.7 & 2.77 & \\
\hline Bioturbated white limestone & 367 & $26-3-13$ & 0.06 & 19 & 150 & -27.3 & 2.98 & \\
\hline Black claystone & 530 & $87-4-80$ & 7.75 & 25 & 315 & -27.6 & -1.28 & 2.1 \\
\hline Black claystone & 530 & $95-2-127$ & 12.61 & 26 & 318 & -26.3 & -1.75 & 2.5 \\
\hline Black claystone & 530 & $97-3-70$ & 19.00 & 27 & 457 & -27.3 & -2.50 & 12.0 \\
\hline Black claystone & 530 & $97-3-70$ & 19.00 & 27 & 457 & -27.3 & -2.68 & 12.0 \\
\hline Black claystone & 530 & $98-3-128$ & 6.72 & 26 & 572 & -27.1 & -1.98 & 1.3 \\
\hline Black claystone & 530 & $105-4-10$ & 2.95 & 28 & 396 & -27.0 & -1.19 & 7.8 \\
\hline Green claystone & 530 & $87-4-64$ & 0.24 & 11 & 6 & -26.7 & 4.19 & 3.2 \\
\hline Green claystone & 530 & $88-3-84$ & 0.23 & 12 & 212 & -27.6 & 3.44 & 1.6 \\
\hline Green claystone & 530 & $90-3-55$ & 0.26 & 10 & 130 & -26.9 & 5.72 & 28.2 \\
\hline Green claystone & 530 & $96-1-70$ & 0.15 & 15 & 40 & -27.6 & 3.12 & 4.7 \\
\hline Green claystone & 530 & $97-3-85$ & 0.32 & 20 & 16 & -26.9 & 1.70 & 8.7 \\
\hline Green claystone & 530 & $97-3-85$ & 0.32 & 19 & 16 & -26.9 & 1.45 & 8.7 \\
\hline \multicolumn{9}{|l|}{ Homogeneous black } \\
\hline claystone & 603 & $57-1-86$ & 2.06 & 25 & 25 & -24.4 & 2.30 & 17.7 \\
\hline \multicolumn{9}{|l|}{ Homogeneous black } \\
\hline claystone & 603 & $63-5-128$ & 2.74 & 30 & 23 & -25.3 & 3.33 & 14.2 \\
\hline \multicolumn{9}{|l|}{ Homogeneous black } \\
\hline claystone & 603 & $64-5-46$ & 1.61 & 28 & 30 & -25.3 & 1.73 & 18.6 \\
\hline \multicolumn{9}{|l|}{ Homogeneous black } \\
\hline claystone & 603 & $65-4-107$ & 1.81 & 28 & 25 & -25.1 & 2.46 & 11.2 \\
\hline \multicolumn{9}{|l|}{ Homogeneous black } \\
\hline claystone & 603 & $75-2-48$ & 1.58 & 28 & 37 & -24.7 & 1.58 & 24.6 \\
\hline \multicolumn{9}{|l|}{ Homogeneous black } \\
\hline claystone & 603 & $75-2-61$ & 1.43 & 30 & 36 & -24.8 & 2.27 & 25.9 \\
\hline Laminated limestone & 603 & $57-1-80$ & 1.41 & 20 & 115 & -26.7 & -0.05 & 78.9 \\
\hline Laminated limestone & 603 & $57-1-93$ & 1.57 & 22 & 126 & -26.5 & -0.66 & 75.9 \\
\hline Laminated limestone & 603 & $65-4-48$ & 0.43 & 34 & 20 & -25.6 & 3.75 & 82.9 \\
\hline Laminated limestone & 603 & $66-3-32$ & 0.54 & 20 & 35 & -26.0 & 2.07 & 72.1 \\
\hline Laminated limestone & 603 & $75-2-70$ & 1.07 & 30 & 62 & -25.5 & 1.42 & 66.2 \\
\hline
\end{tabular}

a mg hydrocarbon/g OC.

\subsection{Diagenetic effects}

Recent marine sediments typically contain $0.01-0.1 \%$ nitrogen by weight, and downcore decreases in TN commonly are observed (e.g. [9]). Much of the initial organic nitrogen $(\mathrm{ON})$ reaching the sediment/water interface is apparently lost during early diagenesis (e.g. [10]). In modern to Miocene marine sediments, the $\delta^{15} \mathrm{~N}$ of $\mathrm{TN}$ ranges between 0 and $13 \%$, with most values clustering between 4 to $8 \%$ (Fig. 2 and 3). It is frequently assumed that the $\mathrm{TN}$ isotopically analyzed is derived mainly from $\mathrm{ON}$, and, indeed, $\delta^{15} \mathrm{~N}$ values of kerogen nitrogen are similar to those of sediment TN (e.g. [11]).

Biological utilization/diagenesis of organic matter can sometimes induce $\mathrm{N}$ isotope fractionation under laboratory conditions (e.g. $[12,13]$ ). These studies imply that microbial breakdown of 


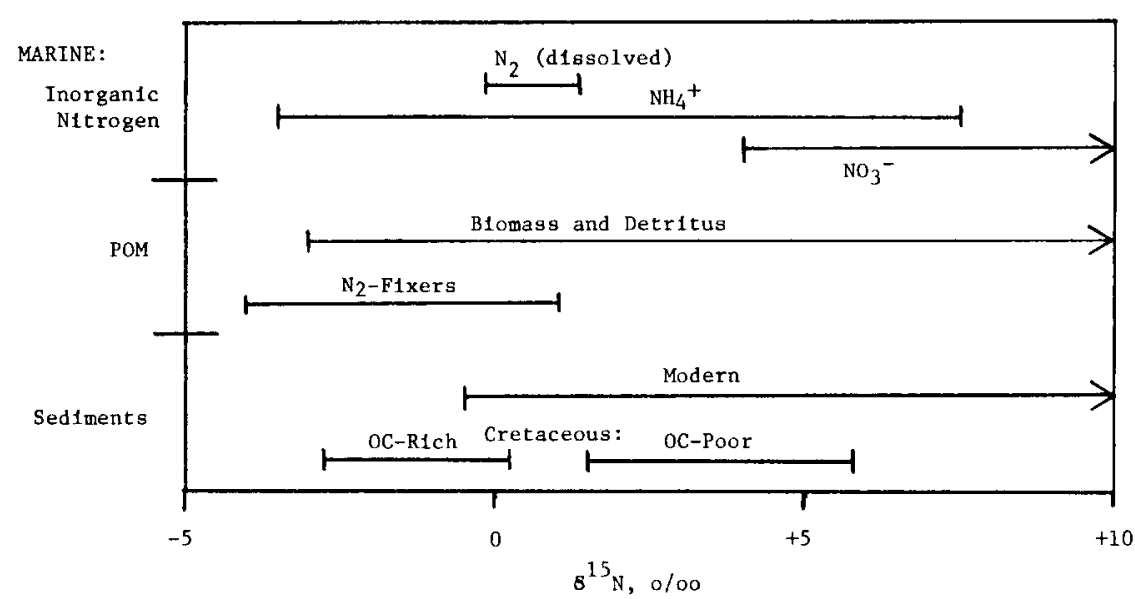

Fig. 2. Ranges of values of $\delta^{15} \mathrm{~N}$ for selected oceanic nitrogen pools (modified from Libes [49]). Values for OC-rich Cretaceous samples ( $>1 \%$ OC, carbonate-free dry wt.) and 530 and for OC-poor $(<0.4 \%$ OC) samples from Sites 367 and 530 are from Table 1.

sedimentary organic matter could enrich or deplete the residual organic matter in ${ }^{15} \mathrm{~N}$. It is likely, however, that the nitrogen remaining in our Cretaceous samples has retained a $\mathrm{N}$ isotope signature which is close to that of the original ON. Clay-rich sediments and sedimentary rocks can have significant adsorption capacities for inorganic nitrogen (IN) compounds, particularly $\mathrm{NH}_{3}$ and $\mathrm{NH}_{4}^{+}$(e.g. $[14,15]$ ), but these IN species generally have $\delta^{15} \mathrm{~N}$ values that are not signifi-

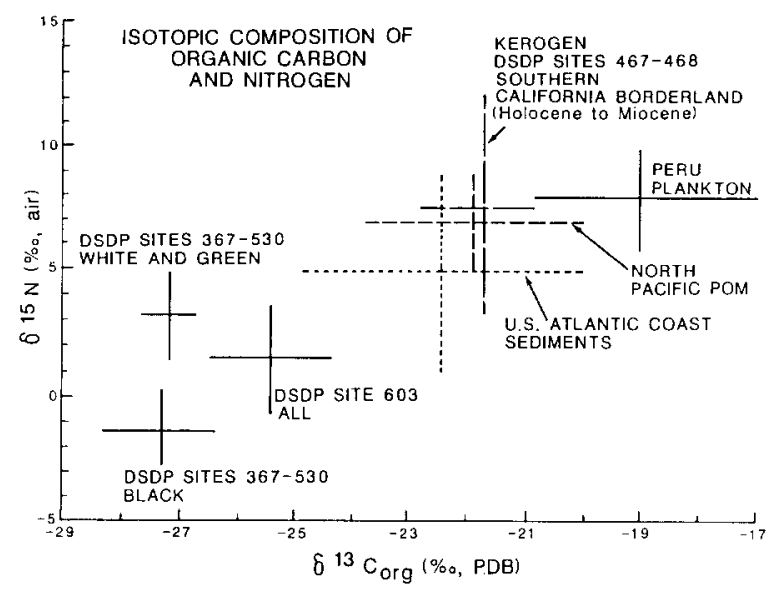

Fig. 3. Ranges of paired values of $\delta^{15} \mathrm{~N}$ and $\delta^{13} \mathrm{C}$ for Peru phytoplankton [49], North Pacific particulate organic matter (POM) [34,49,50], Holocene continental shelf sediments [11,27], Holocene to Miocene kerogen, Southern California Borderland, DSDP Sites 467 and 468 [20], and Cretaceous OC-rich and OC-poor strata, DSDP Sites 367, 530, and 603 (Table 1). cantly different from those of the source ON (e.g. $[16,17])$. Increasing thermal maturation tends to produce heavier $\delta^{15} \mathrm{~N}$ values (e.g. [17]), yet our Cretaceous samples probably were not affected by post-depositional temperature changes since none of these sequences has been exposed to burial temperatures higher than $60^{\circ} \mathrm{C}$.

In pelagic sediments and sedimentary rocks that are low in $\mathrm{OC}$, whole-rock $\mathrm{C} / \mathrm{N}$ ratios may be low because of significant adsorbed IN derived from bacterial degradation of organic matter [14]. On the other hand, OC-rich strata may have relatively high $\mathrm{C} / \mathrm{N}$ ratios as a result of selective loss of nitrogeneous organic compounds and a relatively limited adsorption capacity of the inorganic matrix. For this reason, whole-rock and kerogen $\mathrm{C} / \mathrm{N}$ ratios are not strictly comparable, and the whole-rock $\mathrm{C} / \mathrm{N}$ ratios cannot be used effectively to determine the source or even the relative extent of preservation of the organic matter in ancient sediments [15]. In relatively OC-poor, clay-rich strata, therefore, adsorbed IN might be the predominant form of nitrogen. Data of Waples [15] and references summarized within suggest that the clay-rich insoluble residue of most pelagic marine sediments has the capacity to adsorb up to $0.5 \%$ by weight of exchangable and free IN. Our lightcolored, bioturbated OC-poor samples contain no more than $0.03 \% \mathrm{TN}$, with $\mathrm{C} / \mathrm{N}$ ratios that average $18.4( \pm 6.6)$. On the other hand, the darkcolored, OC-rich samples ( $>1 \%$ OC) contain more than $0.04 \% \mathrm{TN}$ and have $\mathrm{C} / \mathrm{N}$ ratios averaging 
$26.2( \pm 2.3)$. Based on the preceding, we conclude that most of the $\mathrm{N}$ analyzed in our OC-rich Cretaceous samples is $\mathrm{ON}$, and that the OC-poor samples may contain significant amounts of IN, though probably derived from the diagenesis of associated $\mathrm{ON}$.

There are several other $\mathrm{N}$ isotope fractionation effects that may be relevant to our samples. The first effect is the possible fractionation of nitrogen isotopes upon adsorption onto or within clay minerals. Such a mechanism would favor preferential uptake of ${ }^{14} \mathrm{NH}_{4}^{+}$onto clays (e.g. [18]), resulting in lowered $\mathrm{TN} \delta^{15} \mathrm{~N}$ values in such clayrich strata. However, in the case of our samples, those most likely to contain adsorbed ${ }^{14} \mathrm{NH}_{4}^{+}$, the OC-poor limestones and claystones, have higher $\delta^{15} \mathrm{~N}$ values than do the OC-rich sediments. $\mathrm{NH}_{3}$ volatilization/diffusion has been shown to result in preferential removal of ${ }^{14} \mathrm{NH}_{3}$ from dry sediment or soil and $\delta^{15} \mathrm{~N}$ enrichment in the residual $\mathrm{NH}_{4}^{+}$(e.g. [17,19]). Sweeney and Kaplan [16] found porewater ammonium $\delta^{15} \mathrm{~N}$ values were similar to the $\delta^{15} \mathrm{~N}$ of associated sediment $\mathrm{ON}$, with little change in ammonium $\delta^{15} \mathrm{~N}$ with sediment depth. This suggests that there is little net isotope effect associated with ammonium generation, adsorption, or vertical diffusion in marine sediments.

This approach can be extended to evaluate the possibility of post-depositional isotope effects by looking for progressive increases or decreases in isotope abundance through sediment sequences likely to have undergone significant diagenesis. If cumulative diagenetic isotope effects have occurred, increasingly large deviations in sediment $\delta^{15} \mathrm{~N}$ should be encountered. In fact the Cretaceous sequences we have analyzed (Table 1) as well as those examples of recent to Precambrian age do not show consistent or progressive changes in sediment $\delta^{15} \mathrm{~N}$ as a function of sediment depth/age (e.g. $[8,11,20,21,49])$. The results of Simoneit and Mazurek [20] are particularly instructive because their data are for sediments as old as Miocene from locations on the Southern California Borderland that have experienced significant microbial reworking including methanogenesis. Values of $\delta^{15} \mathrm{~N}$ in their samples of OC-rich sediment of Miocene to Recent age range from 3.4 to $11.8 \%$, similar to modern sediment values, yet there is very little overlap between their $\delta^{15} \mathrm{~N}$ (and $\delta^{13} \mathrm{C}$ ) values and those in our Cretaceous samples (Fig. 3). Also, there are no significant downcore variations in $\delta^{15} \mathrm{~N}$ that might suggest cumulative diagenetic changes, and there is no significant relationship between kerogen $\mathrm{H} / \mathrm{C}$ ratios and $\mathrm{TN}$ $\delta^{15} \mathrm{~N}$ values. The kerogen samples from the Southern California Borderland with the highest $\mathrm{H} / \mathrm{C}$ ratios in kerogen also are characterized by the highest $\delta^{15} \mathrm{~N}$ values, opposite to the relationship that we observed for our Cretaceous samples (Table 1). We conclude that processes other than post-depositional alteration are most important in controlling $\mathrm{N}$-isotope abundance in the sediments we have analyzed and in marine sediments in general. This is a conclusion also recently reached by Rigby and Batts [7] in their interpretation of $\mathrm{N}$ isotope abundances in Cretaceous oil shales.

\subsection{Source effects}

The majority of samples of both black and white lithologies at Site 367 and black and green lithologies at Site 530 are dominated by marine organic matter of varying preservation as indicated by (1) variable, but not low, values of HI (Table 1); (2) similar $\delta^{13} \mathrm{C}$ values in both lithologies at each site (e.g. [3]); and (3) other organic geochemical and petrographic criteria (e.g. [22,23]). In contrast, the organic matter at Site 603 is mainly of terrigenous origin on the basis of optical [24] and other organic geochemical parameters [25]. This interpretation is strengthened by the inorganic geochemical character of the sequence as well as the sedimentary structures [26]. The C and $\mathrm{N}$ isotope values for these Cretaceous terrestrially-derived sediments are, therefore, equal to or higher than those of Cretaceous marine-derived sediments (Fig. 3), which is much different from the situation today in which values of $\delta^{15} \mathrm{~N}$ and $\delta^{13} \mathrm{C}$ generally are lower in terrestrial than marine-dominated sediments (e.g. [11,27]).

The $\mathrm{C}$ and $\mathrm{N}$ isotope compositions of organic matter in the laminated brown to white limestones at Site 603 are, one the other hand, transitional between those of the 603 black claystones and those of the black, OC-rich lithologies at Sites 367 and 530 (Fig. 3). On the basis of these and other data [26], we interpret the organic matter in the limestones at Site 603 as a mixture between marine and terrestrial end-members. Cretaceous terrestrial organic matter then is apparently char- 
acterized by $\delta^{15} \mathrm{~N}$ values of between +1 and $+4 \%$ and $\delta^{13} \mathrm{C}$ values of -24 to $-26 \%$, whereas, marine organic matter had a range of $\delta^{15} \mathrm{~N}$ values of -3 to $+5 \%$ and a range of $\delta^{13} \mathrm{C}$ values of about -26 to $-29 \%$.

We are impressed with the fact that the nitrogen in all of the OC-rich strata (i.e. black lithologies from Sites 367 and 530), are isotopically lighter than marine sediments found elsewhere in the modern and ancient marine sedimentary records. This raises the possibility that the early Cretaceous pelagic $\mathrm{N}$ cycle (as a source of sediment $N$ ) operated differently than at other times. We consider below several water column scenarios that may explain the observed low $\delta^{15} \mathrm{~N}$ values for our Cretaceous samples, and the dark OC-rich lithologies in particular.

The largest isotopic fractionation involving marine nitrate occurs during denitrification (e.g. [28]) which, in an oceanic setting, is most prevalent within the sub-oxic waters of a mid-water oxygen minimum zone (OMZ). Denitrification produces $\mathrm{N}_{X} \mathrm{O}_{Y}$ molecules that are enriched in ${ }^{14} \mathrm{~N}$, leaving the remaining nitrate reservoir enriched in ${ }^{15} \mathrm{~N}$, i.e. isotopically heavier. Therefore, during deposition of Lower to middle Cretaceous strata in general, and the more OC-rich beds in particular, an expanded and intensified OMZ (e.g. $[29,30])$ should have resulted in isotopically heavier nitrate. If this nitrate was upwelled into the surface waters and utilized by phytoplankton (primarily dinoflagellates and coccoliths), the resulting particulate organic matter should be isotopically heavier reflecting the heavier nitrate source. Because such a scenario produces elevated rather than low sediment $\delta^{15} \mathrm{~N}$, denitrification and subsequent isotopic changes to the nitrate pool followed by phytoplankton uptake and sedimentation are not indicated by the sediment ${ }^{15} \mathrm{~N}$ depletions we observe.

The lower $\delta^{15} \mathrm{~N}$ values in the black marlstones and claystones could be interpreted as representing periods of higher biological $\mathrm{N}$ isotope fractionation due to low biologic nitrate demand (low productivity) relative to nitrate availability. Such conditions might occur under light or phosphate limitation, as suggested by Wada [12]. However, if there was an abundant supply of nitrate (relative to demand), it is difficult to see how phosphorus limitation could occur. This is because there is no simple mechanism of decoupling availability of phosphate from that of nitrate other than by denitrification discussed above. There is no evidence for a high rate of incorporation of phosphate into deep-sea sediments during the Early to middle Cretaceous (e.g. [31]), nor can we envision a mechanism by which the influxes of inorganic phosphorus and nitrogen from erosion may have been decoupled. It is therefore difficult to explain the large $\mathrm{N}$ isotope difference between the OC-rich vs. -poor beds simply by changing the rate of productivity (and $\mathrm{N}$ isotope fractionation) of nitrate-utilizing phytoplankton in the watercolumn.

In this regard, the $\delta^{15} \mathrm{~N}$ of particulate organic material trapped in the modern Sargasso Sea varies seasonally with an approximate amplitude of $2.5 \%$ [32]. There is a significant correlation between the $\delta^{15} \mathrm{~N}$ of organic matter and the calculated flux of organic matter to the sediment traps in that study, with lowest $\delta^{15} \mathrm{~N}$ values $(+0.5 \%$ ) corresponding to times of highest organic-matter flux rates. Altabet and Deuser [32] attribute the lighter $\delta^{15} \mathrm{~N}$ values to periodically greater concentrations of nitrate during seasonal overturn and mixing through the thermocline, and the heavier values to gradual nitrate depletion (and isotopically heavier residual nitrate) during times of low overturn. This explanation might be applied to our data except that the amplitude of the overall $\mathrm{N}$ isotope changes in our data is more than a factor of two larger, and the $\delta^{15} \mathrm{~N}$ values of the black beds are much lower than their lowest values. We conclude that neither $\mathrm{N}$ isotopic enrichment during drawdown of nitrate nor changes in the $\delta^{15} \mathrm{~N}$ of nitrate supplied from deeper waters can adequately explain the $\mathrm{N}$ isotopic differences between the $\mathrm{OC}$ rich and -poor sediments we measured.

The above discussion presumes that nitrate is the primary inorganic nitrogen source for plankton production, while nitrogen sources other than nitrate can be important in the contemporary ocean. Under such circumstances $\mathrm{NH}_{4}^{+}$, urea, or $\mathrm{N}_{2}$ can be utilized as an $\mathrm{N}$ source for primary production (e.g. [33]). Lack of data makes it difficult to speculate as to what isotopic abundances may be characteristic of $\mathrm{NH}_{4}^{+}$- or urea-based plankton communities. However, in the north Pacific Ocean, Mullin et al. [34] and Saino and Hattori [35] found lower plankton $\delta^{15} \mathrm{~N}$ values when nitrate 
was not the dominant form of nitrogen assimilated. Aside from $\mathrm{NH}_{4}^{+}$formation being favored under reducing conditions associated with an expanded $O M Z$, it is not clear if utilization of these $\mathrm{N}$ species was relevant to the Cretaceous marine $\mathrm{N}$ cycle and subsequent sediment formation.

As an alternative, we suggest that extensive denitrification in largely anoxic or suboxic OMZ and slow deep-water turnover greatly reduced the supply of available combined nitrogen to Atlantic surface waters. Under such circumstances, $\mathrm{N}_{2}$-fixing species (blue-green algae or cyanobacteria) may have become important in the phytoplankton community. The blue-greens usually are less abundant than other photosynthetic organisms in nonnitrate-limited temperate marine environments [36], but it has been shown that blue-green algae in tropical and subtropical seas contribute isotopically light $\mathrm{N}$ to the organic pool there $[37,38]$. Marine blue-green algae Oscillatoria spp., as well as other plants/microbes associated with $\mathrm{N}_{2}$ fixation have biomass $\delta^{15} \mathrm{~N}$ values ranging from -4 to $+1 \%$ (e.g. $[18,38]$ ) overlapping the $\delta^{15} \mathrm{~N}$ range of Cretaceous OC-rich sediment (Fig. 2). We speculate, therefore, that under conditions of reduced nitrate availability, phytoplankton capable of using an alternate source of nitrogen such as $\mathrm{N}_{2}$ may have become quantitatively important, the sedimentary remains of which are the source of the sediment ${ }^{15} \mathrm{~N}$ depletion we have encountered. $\mathrm{N}_{2}$ fixation was also invoked by Rigby and Batts [7] to explain low $\delta^{15} \mathrm{~N}$ values they found in Australian Cretaceous-age oil shales. Such an increase in $\mathrm{N}_{2}$-fixing species may have occurred within a total phytoplankton community whose production, because of low nitrate availability, was much reduced as suggested by Bralower and Thierstein [39].

The black laminated marlstones at Site 367 contain predominantly amorphous organic matter (e.g. [22]), which may be characteristic of sediment having a blue-green algal source. Coccolith remains are much less abundant in these marlstones than in the intervening white limestones. Occasional thin, white laminae of coccolith debris do occur, however, in the black strata, suggesting that calcareous nannoplankton were present in the surface water, but only occasionally were supplied with utilizable nitrogen to produce coccolith-rich sediment layers. Apparently there is little dif- ference in composition or degree of preservation of coccolith assemblages between the two lithologies which have $35-65 \% \mathrm{CaCO}_{3}[40,41]$, suggesting that low carbonate production rather than increased carbonate dissolution produced these marlstone beds.

The possibility that blue-green algae may have been important primary producers during deposition of Cretaceous black shales, at least in the Atlantic ocean, was suggested by Berger and Roth [42] following a model proposed by Piper and Codispoti [43]. These researchers discussed the possibility that extensive denitrification decreased nitrate availability of plankton during times of widespread anoxia in oceanic deep-water masses. They reasoned that the concentration of dissolved phosphate in seawater should increase sufficiently to cause widespread inorganic precipitation of apatite because phosphate was not utilized by phytoplankton due to depletion of nitrate. In their model, major economic phosphorite deposits should thus correspond to "Oceanic Anoxic Events" (OAE's) [44]. However, Arthur and Jenkyns [31] have shown that, in the Cretaceous, phosphorites and OAE's do not coincide. Hence, even though dissolved seawater phosphate concentrations may have been relatively high during extensive Early Cretaceous denitrification phases, there was no important phosphate mineral formation then. In fact, we would argue that the possible diminished productivity associated with bluegreen algae communities also decreased the possibility for transfer of phosphate to sediments and phosphate mineral formation.

The $\delta^{15} \mathrm{~N}$ values in both the bioturbated limestones (Site 367) and green claystones (Site 530) are significantly higher than those in the black marlstones and claystones, and more closely overlap the range of $\delta^{15} \mathrm{~N}$ values for modern marine organic matter (Figs. 2 and 3). The limestones and claystones thus appear to record historically "normal" conditions of increased oxygenation of deep-water masses, an increased supply of nutrients, particularly nitrate, to the surface waters and higher phytoplankton productivity.

At Site 367 and 530 some of the organic matter may have been redeposited by turbidity currents from shallower sites of accumulation on the shelf and slope under the influence of an expanded and intensified OMZ [5,30,45,46]. During the Creta- 
ceous, both Sites 367 and 530 were located along west-facing, low-latitude continental margins along which wind-driven upwelling of deeper water is expected (e.g. $[4,47])$. Therefore, these environments were likely characterized by profound variations in productivity due to the influence of climatic fluctuations on upwelling intensity, expansion and intensification of the $O M Z$, and supply of nitrate to surface waters.

Site 603 , on the other hand, seems to have experienced low marine productivity overall, and a supply of terrestrially-derived organic matter that was transported by turbidity currents to deep basinal sites of accumulation [26]. The more pelagic phases at Site 603 (white limestones) have low concentrations of organic matter, but the isotopic composition of that organic matter is similar or transitional to that of organic matter in the black marlstones and claystones (Table 1). The relative isotopic constancy within the terrestrially dominated Cretaceous strata from Site 603, and the isotopic similarity between this material and land-derived nitrogen in contemporary marine sediments $[11,27]$ suggests that the presumed episodic changes in marine $\mathrm{N}$ biogeochemistry encountered at Sites 367 and 530 did not coincide with analogous changes on land.

\section{Conclusions}

The unusually low $\delta^{15} \mathrm{~N}$ found in early to middle Cretaceous beds rich in marine organic matter from two separate eastern Atlantic Ocean basins is an unambiguous indication that the nitrogen contained in these strata are the end result of biogeochemical processes that substantially differ from those that operated on the nitrogen contained in (1) intervening organic-poor strata, and (2) younger marine sediments. Lack of comparable isotope abundances in diagenetically altered marine sediments, and lack of progressive, downcore $\delta^{15} \mathrm{~N}$ decreases in Cretaceous and younger sediment sequences make it very unlikely that post-depositional isotopic alterations are responsible for this reoccurring sediment ${ }^{15} \mathrm{~N}$ depletion. Alternatively, several lines of evidence indicate that the $\mathrm{N}$ isotope abundance of the source organic matter is the overriding determinant of the sediment $\delta^{15} \mathrm{~N}$ we and others have measured. If this is so, episodic changes in pelagic nitrogen biogeo- chemistry are indicated by the alternating moderate to low $\delta^{15} \mathrm{~N}$ values in the Cretaceous marine sediment sequences analyzed. Such changes may be directly related to historic variation in euphotic zone nitrate availability and utilization as influenced by rates of denitrification, upwelling, and deep-water turnover. During times of reduced nitrate availability, $\mathrm{N}_{2}$ fixation may have provided an alternate $\mathrm{N}$ source for plankton, the characteristic ${ }^{15} \mathrm{~N}$-depleted remains of which may compose the bulk of the sediment $\mathrm{N}$ encountered in OC-rich Cretaceous strata. In contrast, the coccolith-rich, bioturbated limestones and claystones interbedded between the above strata seem to record conditions of increased upwelling, bottom water oxygenation, and surface-water nutrient availability. Lack of isotopic difference between contemporary terrestrially-derived marine sediments and terrestrially-supplied Cretaceous sedimentary material from the western Atlantic (Site 603) argues that the presumed historic changes in Cretaceous marine $\mathrm{N}$ biogeochemistry did not extend to the terrestrial environment. The geographic and historic extent of the sediment $\mathrm{N}$ isotope variations we have observed and their paleoceanographic significance deserve further study.

\section{Acknowledgements}

We thank E. Spiker, G. Claypool, and M. Delaney for helpful criticism. D. Des Marais (NASA-Ames Research Center) generously provided analytical facilities. G.H.R. supported in part by NASA Joint Research Interchange grant No. NCA2-1R660-403. M.A.A. acknowledges the support of NSF grant OCE84-10178. Support for W.E.D. was provided by the USGS Program in Climate Change.

\section{References}

1 M.A. Arthur and W.E. Dean, Cretaceous paleoceanography, in: Decade of North American Geology, Western North Atlantic Synthesis Volume, B.E. Tucholke and P.R. Vogt, eds., pp., Geol. Soc. Products, D.A.V. Stow and D.J.W. Piper, eds., Geol. Soc. Spec. Publ. 15, 527-559, 1986.

2 P.A. Meyers and R.M. Mitterer, Deep ocean black shales: Organic geochemistry and paleoceanographic setting-introduction and overview, Mar. Geol. 70, 1-8, 1986.

3 W.E. Dean, M.A. Arthur and G.E. Claypool, Depletion of 
${ }^{13} \mathrm{C}$ in Cretaceous marine organic matter: source, diagenetic, or environmental signal?, Mar. Geol. 70, 119-158, 1986.

4 J.T. Parrish and R.L. Curtis, Atmospheric circulation, upwelling, and organic-rich rocks in the Mesozoic and Cenozoic, Palaeogeogr., Palaeoclim., Palaeoecol., 40, 67-101, 1982.

5 W.E. Dean, M.A. Arthur and D.A.V. Stow, Origin and geochemistry of Cretaceous deep-sea black shales and multicolored claystones, with emphasis on Deep Sea Drilling Project Site 530, Southern Angola Basin, in: W.W. Hay, J.-C. Sibuet et al., Initial Reports of the Deep Sea Drilling Project, 75, pp. 819-844, U.S. Government Printing Office, Washington, D.C., 1984.

6 M.A. Arthur, S.O. Schlanger and H.C. Jenkyns, The Cenomanian-Turonian oceanic anoxic event, 11, Paleoceanographic controls on organic matter production and preservation, in: Marine Petroleum Source Rocks, J. Brooks and A. Fleet, eds., Geological Society of London, 1986.

7 D. Rigby and B.D. Batts, The isotopic composition of nitrogen in Australian coals and oil shales, Chem. Geol. 58, 273-282, 1986.

8 J.M. Hayes, I.R. Kaplan and K.W. Wedeking, Precambrian organic geochemistry, preservation of the record, in: Earth's Earliest Biosphere, J.W. Schopt, ed., pp. 93-132, Princeton University Press, 1983.

9 D.W. Waples and J.R. Sloan, Carbon and nitrogen diagenesis in deep sea sediments, Geochim. Cosmochim. Acta 44, 1463-1470, 1980.

10 M.L. Bender and D.T. Heggie, Fate of organic carbon reaching the deep sea floor: a status report, Geochim. Cosmochim. Acta 48, 977-986, 1984.

11 K.E. Peters, R.E. Sweeney and I.R. Kaplan, Correlation of carbon and nitrogen isotope ratios in sedimentary organic matter, Limnol. Oceanogr. 23, 598-604, 1978.

12 E. Wada, Nitrogen isotope fractionation and its significance in biogeochemical processes occurring in marine environments, in: Isotope Marine Chemistry, E.D. Goldberg, Y. Horibe and K. Saruhashi, eds., pp. 375-398, Uchida Rokakuho, Tokyo, 1980.

13 S.A. Macko and M.L.F. Estep, Microbial alteration of stable nitrogen and carbon isotopic compositions of organic matter, Org. geocheem. 6, 787-790, 1984.

14 P.J. Muller, $\mathrm{C} / \mathrm{N}$ ratios in Pacific deep-sea sediments: effect of inorganic ammonium and organic nitrogen compounds sorbed by clays, Geochim. Cosmochim. Acta 41, $765-776,1977$.

15 D.W. Waples, Organic and inorganic nitrogen in sediments from Leg 80, Deep Sea Drilling Project, in: P.C. de Graciansky, C.W. Poag et al., Initial Reports of Deep Sea Drilling Project, 80, pp. 993-998. U.S. Government Printing Office, Washington, D.C., 1985.

16 R.E. Sweeney and I.R. Kaplan, Natural abundances of $\mathrm{N}-15$ as a source indicator for near-shore marine sedimentary and dissolved nitrogen, Mar. Chem. 9, 81-94, 1980.

17 B.G. Rohrback, K.E. Peters, R.E. Sweeney and I.R. Kaplan, Ammonia formation in laboratory simulated thermal maturation: implications related to the origin of nitrogen in natural gas, in: Advances in Organic Geochemistry, 1981, pp. 819-823, Wiley, 1983.
18 C.C. Delwiche and P.L. Steyn, Nitrogen isotope fractionation in soils and microbial reactions, Environ. Sci. Technol 4, 929-939, 1970.

19 E. Wada, R. Shibata and T. Torii, N-15 abundance in Antarctica: origin of soil nitrogen and ecological implications, Nature 292, 327-329, 1981.

20 B.R.T. Simoneit and M.A. Mazurek, Organic geochemistry of sediments from the Southern California Borderland, Deep Sea Drilling Project Leg 63, in: R.S. Yeats, B.U. Haq et al., Initial Reports of the Deep Sea Drilling Project, 63, pp. 837-853, U.S. Government Printing Office, Washington, D.C., 1981.

21 P.A. Meyers, K.W. Dunham and G.H. Rau, Geochemical characteristics of organic matter in light-dark cycles in Plio-Pleistocene sediments from DSDP Site 532, Walvis Ridge Continental Terrace, in: E.T. Degens, P.A. Meyers and S.C. Brassell, eds., Biogeochemistry of Black Shales, SCOPE/UNEP, Hamburg, 1986

22 C.P. Summerhayes, Organic facies of middle Cretaceous black shales in deep North Atlantic, Am. Assoc, Pet. Geol. Bull. 65, 2364-2380, 1981.

23 P.A. Meyers, S.C. Brassel and A.Y. Huc, Geochemistry of organic carbon in South Atlantic sediments from Deep Sea Drilling Project Leg 75, in: W.W. Hay, J.-C. Sibuet et al., Initial Reports of the Deep Sea Drilling Project, 75, pp. 967-981, U.S. Government Printing Office, Washington, D.C., 1984.

24 D. Habib, and W. Drugg, Cretaceous dinoflagellates from Site 603, in: $J$. van Hinte, S.W. Wise et a1., Initial Reports of the Deep Sea Drilling Project, 93, U.S. Government Printing Office, Washington, D.C., 1986.

25 P.A. Meyers, Synthesis of organic geochemical studies, DSDP 93, North American continental margin, in: J. van Hinte, S.W. Wise et al., Initial Reports of the Deep Sea Drilling Project, 93, U.S. Government Printing Office, Washington, D.C., 1986.

26 W.E. Dean and M.A. Arthur, Inorganic and organic geochemistry of rocks and sediments recovered from the lower continental rise, North American Basin, Site 603, Deep Sea Drilling Project Leg 93, in: J. van Hinte, S.W. Wise et al., Initial Reports of the Deep Sea Drilling Project, 93, U.S Government Printing Office, Washington, D.C., 1986.

27 S.A. Macko, Sources of organic nitrogen in mid-Atlantic coastal bays and continental shelf sediments of the United States: isotopic evidence, Carnegie Inst., Washington, Annu. Rep. Geophys. Lab. 1982-1983, pp. 328-329, 1983.

28 D.J. Cline and I.R. Kaplan, Isotopic fractionation of dissolved nitrate during denitrification in the eastern tropical North Pacific Ocean, Mar. Chem. 3, 271-299, 1975.

29 M.A. Arthur, North Atlantic Cretaceous black shales: the record at Site 398 and a brief comparison with other occurrences, in: W.B.F. Ryan and J.-C. Sibuet et al., Inititial Reports of the Deep Sea Drilling Project, 47, pp. 719-751, U.S. Government Printing Office, Washington, D.C., 1979.

30 W.E. Dean and J.V. Gardner, Origin and geochemistry of redox cycles of Jurassic to Eocene age, Cape Verde Basin (DSDP Site 367), continental margin of Northwest Africa, in: Nature and Origin of Cretaceous Carbon-Rich Facies, S.O. Schlanger and M.B. Cita, eds., pp. 55-78, Academic Press, London, 1982. 
31 M.A. Arthur and H.C. Jenkyns, Phosphorites and paleoceanography, Oceanol. Acta SP, pp. 83-96, 1981.

32 M.A. Altabet and W.G. Deuser, Seasonal variations in natural abundance of ${ }^{15} \mathrm{~N}$ in particles sinking to the deep Sargasso Sea, Nature 3165, 218-220, 1985.

33 J.J. McCarthy and E.J. Carpenter, Nitrogen cycling in near-surface waters in the ocean, in: Nitrogen in the Marine Environment, E.J. Carpenter and D.S. Capone, eds, pp. 487-512, Academic Press, New York, N.Y., 1983.

34 M.M. Mullin, G.H. Rau and R.W. Eppley, Stable nitrogen isotopes in zooplankton: some geographic and temporal variations in the North Pacific, Limnol. Oceanogr. 29, $1267-1273,1984$.

35 T. Saino and A. Hattori, Variation of ${ }^{15} \mathrm{~N}$ natural abundance of suspended organic matter in shallow oceanic waters, in: Marine and Estuarine Geochemistry, A.C. Sigleo and A. Hattori, eds., pp. 1-13, Lewis, Chelsea, 1985.

36 E.J. Carpenter, Nitrogen fixation by marine Oscillatoria (Trichodesmium) in the world's oceans, in: Nitrogen in the Marine Environment, E.J. Carpenter and D.S. Capone, eds., pp. 65-103, Academic Press, New York, N.Y., 1983.

37 E. Wada and A. Hattori, Natural abundance of N-15 in particulate organic matter in the North Pacific Ocean, Geochim. Cosmochim. Acta 40, 249-251, 1976.

$38 \mathrm{M}$. Minagawa and E. Wada, Nitrogen isotope ratios of red tide organisms in the East China Sea: a characterization of biological nitrogen fixation, Mar. Chem. 19, 245-259, 1986.

39 T.J. Bralower and H.R. Thierstein, Low productivity and slow deep-water circulation in mid-Cretaceous oceans, Geology 12, 614-618, 1984.

40 H.R. Thierstein, Oxygen and carbon isotope fluctuations in cyclic mid-Cretaceous diagenetic effects, Trans. Am. Geophys. Union, 64, 733, 1983.

41 P.R. Roth, Calcareous nannofossils in mid-Cretaceous black shale cycles of the Atlantic and Pacific, effects of diagenesis, Trans. Am. Geophys. Union, 64, 733-734, 1983.
42 W.H. Berger and P.H. Roth, Oceanic micropaleontology: progress and prospect, Rev. Geophys. Space Phys. 13, $560-585,1975$.

43 D.Z. Piper and L.A. Codispoti, Marine phosphorite deposits and the nitrogen cycle, Science $188,15-18,1975$.

44 S.O. Schlanger and H.C. Jenkyns, Cretaceous oceanic anoxic events-causes and consequences, Geol. Mijnb. 55, 179-184. 1976.

45 W.E. Dean, W.W. Hay and J.-C. Sibuet, Geologic evolution, sedimentation, and paleoenvironments of the Angola Basin and adjacent Walvis Ridge: synthesis of results of Deep Sea Drilling Project Leg 75, in: W.W. Hay, J.-C. Sibuet et al., Initial Reports of the Deep Sea Drilling Project, 75, pp. 509-542, U.S. Government Printing Office, Washington, D.C., 1984.

46 D.A.V. Stow and W.E. Dean, Middle Cretaceous black shales at Site 530 in the southeastern Angola Basin, in: W.W. Hay, J.-C. Sibuet et al., Initial Reports of the Deep Sea Drilling Project, 75, pp. 809-817, U.S. Government Printing Office, Washington, D.C., 1984.

47 M.A. Arthur and J.H. Natland, Carbonaceous sediments in the North and South Atlantic: the role of salinity in stable stratification of Early Cretaceous basins, in: Deep Drilling Results in the Atlantic Ocean: Continental Margins and Paleoenvironment, M. Talwani, W.W. Hay and W.B.F. Ryan, eds., Am. Geophys. Union, Maurice Ewing Ser. 3, 29-344, 1979.

48 J. Sclater, S. Hellinger and C. Tapscott, The paleobathymetry of the Atlantic Ocean from the Jurassic to the present, J. Geol. 85, 509-552, 1977.

$49 \mathrm{~K}$. Libes, Stable isotope geochemistry of nitrogen in marine particulates, 288 pp., Ph.D. Thesis, WHOI/MIT, 1983.

50 G.H. Rau, B . Jones and D.J. Des Marais, POM C-13/C-12 and $\mathrm{N}-15 / \mathrm{N}-14$ variations during OPUS II, Leg 3 : implications for $\mathrm{C}$ and $\mathrm{N}$ cycle heterogeneity, Trans. Am. Geophys. Union 64, 1078, 1983. 